\title{
Minat Belajar Peserta Didik SMP Pada Pembelajaran STEM dengan Media Robot Edukasi
}

\author{
Abdul Latip ${ }^{1 *}$ \\ $1^{*}$ Program Studi Pendidikan IPA, Universitas Garut, \\ Jalan Samarang No, 52 A, Garut \\ *E-mail: abdullatip@uniga.ac.id
}

\begin{abstract}
Abstrak
Penelitian ini bertujuan untuk menggambarkan minat belajar peserta didik SMP pada pembelajaran STEM dengan media robot edukasi (STEM-Robotik). Penelitian ini menggunakan metode deskriptif dengan sampel penelitian sebanyak 47 peserta didik SMP swasta di Kota Bandung yang mendapatkan pembelajaran STEM-Robotik selama satu semester. Instrumen yang digunakan merupakan kuisioner yang menggali 3 aspek minat belajar peserta didik dalam pembelajaran STEM-Robotik yaitu perhatian peserta didik, keterlibatan peserta didik, dan manfaat pembelajaran. Hasil penelitian menunjukkan bahwa, 1) Sebanyak $61,8 \%$ peserta didik memberikan perhatian yang baik dalam pembelajaran STEM-Robotik. 2) Sebanyak $73,4 \%$ peserta didik menunjukkan keterlibatan yang baik dalam pembelajaran STEM-Robotik, dan 3) Sebanyak 71,64\% peserta didik mendapatkan manfaat yang baik dalam pembelajaran STEM-Robotik. Hasil tersebut menunjukkan bahwa secara umum peserta didik menunjukkan minat belajar yang baik dalam pembelajaran STEM-Robotik.
\end{abstract}

Kata kunci: Minat belajar, STEM, Robotik

\section{Abstract}

The study aims to describe the junior high school students' interest in STEM learning using educational robotic media (STEM-Robotics). This study used a descriptive method with a research sample of 47 students of private junior high school in Bandung who received STEM-Robotics learning for one semester. The instrument used a questionnaire that explored 3 aspects of students' learning interest in STEM-Robotics learning, namely students' attention, student involvement, and learning benefits. The results showed that, 1) $61.8 \%$ of students gave good attention to STEM-Robotics learning. 2) $73.4 \%$ of students showed good involvement in STEM-Robotics learning, and 3) $71.6 \%$ of students got good benefits in STEM-Robotics learning. These results indicate that the students showed a good learning interest in STEM-Robotics learning..

Keywords: Learning interest, STEM, Robotics

Article History: Received: 6 November 2020 Accepted: 6 November 2020

Revised : 10 November 2020

Published: 20 November 2020

How to cite: Latip, A. (2019). Minat Belajar Peserta Didik SMP Pada Pembelajaran STEM dengan Media Robot Edukasi, 1(2). pp. 90 - 96. Retrieved from http://jurnal.fkip.unmul.ac.id/index.php/JLPF

Copyright ( November 2020, Jurnal Literasi Pendidikan Fisika 
Minat Belajar Peserta....

\section{PENDAHULUAN}

STEM merupakan salah satu pendekatan yang bisa mengakomodasi pengembangan berbagai keterampilan dan pelibatan teknologi dalam pembelajaran yang dilaksanakan di kelas. Pada implementasinya, STEM dapat menyajikan science, technology, engineering dan mathematic secara terintegrasi. Pada konteks yang lebih luas, STEM merupakan subjek pelajaran yang fokus dalam pengembangan keterampilan yang bertujuan mempersiapkan siswa agar berhasil menghadapi dunia kerja global (Lantz, 2009). Pendapat lain menyatakan bahwa STEM merupakan alternatif pembelajaran yang melatih peserta didik dalam menerapkan pengetahuannya untuk membuat desain sebagai bentuk pemecahan masalah lingkungan dengan memanfaatkan teknologi (Permanasari, A., 2016).

Pada perkembangannya, implementasi STEM dalam pembelajaran di kelas sering dikolaborasikan dengan bidang lain atau dengan menggunakan alat dan media lain. Misalnya kolaborassi STEM dengan bidang seni yang kemudian di kenal dengan STEAM (science, technology, engginering, art and mathematic). Pada implementasi lainnya, STEM juga bisa diintegrasikan dengan robot edukasi sebagai alat bantu pembelajaran yang menjadi bagian dari pengembangan desain rekayasa dan teknologi. Withehead (2010) menyatakan bahwa robotik merupakan salah satu bentuk teknologi yang dapat digunakan oleh guru untuk mengembangkan kurikulum STEM yang lebih spesifik pada bagian teknologi dan rekayasa.

Integrasi robot edukasi dalam STEM juga dapat menciptakan lingkungan yang mendorong pada peningkatan aktivitas hands on, kreativitas dan pemecahan masalah (Jiea, et al, 2018), menciptakan pembelajaran yang lebih bermakna dan membekali pengalaman aplikasi teknologi kepada peserta didik (Carik dan Guven, 2019) serta meningkatkan keterampilan dasar STEM seperti keterampilan matematis, metode ilmiah dan keterampilan dalam desain rekayasa (Eguchi, 2013; Karaahmetoglu dan Korkmaz, 2019). Pada keterampilan yang lebih luas, integrasi robot edukasi dalam STEM juga dapat meningkatkan keterampilan kolaboratif peserta didik (Latip, A., et al., 2020).

Selain mengembangkan berbagai keterampilan, integrasi robot edukasi dalam STEM pun dapat meningkatkan minat para peserta didik terhadap STEM, baik dalam pembelajaran STEM maupun dalam pemilihan karir masa depan yang berkaitan dengan STEM (Ebelt, 2012; Khanlari, 2013; Mosley, Ardito dan Scollins, 2016; Chen dan Chang, 2018). Namun demikian, meskipun robotik ini sudah populer dalam bidang pendidikan, fakta di lapangan menunjukkan bahwa robotik masih dijadikan sebagai ekstrakurikuler yang tidak wajib dipelajari oleh semua peserta didik dan belum masuk mata pelajaran reguler hampir di semua kurikulum (Gura, 2011 ; Eguchi, 2013). Kondisi tersebut menjadikan tidak semua peserta didik bisa memiliki kesempatan dan minat belajar yang sama terhadap STEM robotik.

Pada salah satu SMP swasta di kota Bandung, STEM robotik dijadikan sebagai mata pelajaran pada kurikulum reguler dengan durasi $2 \times 40$ menit per minggu. Pembelajaran STEM Robotik yang dilaksanakan memiliki fokus pada materi tentang robot NXT dan arduino dengan tujuan memberikan dasar-dasar keterampilan rekayasa serta teknologi dalam robotik dan coding (Latip, A dan Hardinata, A., 2020). Pada pembelajaran STEM Robotik yang dilaksanakan, peserta didik diajak terlibat langsung baik dalam aktivitas hands on maupun minds on sehingga diharapkan mampu meningkatkan minat belajar dalam berbagai aspek. Berdasarkan hal tersebut, maka pada penelitian ini dilakukan pemetaan minat belajar peserta didik SMP setelah satu semester melaksanakan pembelajaran STEM dengan media robot edukasi (STEM Robotik).

\section{METODE}

Metode penelitian yang digunakan dalam penelitian ini adalah metode deskriptif dengan fokus pada deskripsi data kuantitatif mengenai minat peserta didik terhadap pembelajaran STEM robotik pada tiga aspek, yaitu perhatian peserta didik selama mengikuti pembelajaran, keterlibatan peserta didik selama pembelajaran, dan manfaat yang diperoleh peserta didik dari pembelajaran STEM robotik. Penelitian ini 
Minat Belajar Peserta....

melibatkan 47 peserta didik SMP swasta di Kota Bandung yang telah mendapatkan pembelajaran STEM robotik selama satu semester.

Instrumen yang digunakan berupa kuisioner yang menggali minat belajar peserta didik dari tiga aspek, yaitu aspek perhatian peserta didik terdiri dari 6 pertnyataan positif, aspek keterlibatan peserta didik terdiri dari 2 pernyataan positif, dan aspek manfaat yang didapatkan peserta didik terdiri dari 5 pernyataan positif.

Kuisioner yang diberikan menggunakan skala Guttmen yang menuntut jawaban tegas dari peserta didik mengenai aspek-aspek minat belajar pada pembelajaran STEM robotik. Kuisioner ini diberikan kepada peserta didik pada akhir semester 1 tahun pelajaran 2019/2020 pasca para peserta didik menyelesaikan pembelajaran reguler pada mata pelajaran STEM Robotik. Data hasil kuisioner diolah dan dianalisis secara kuantitatif dengan mengonversinya dalam bentuk persentase untuk setiap indikator dan aspek.

\section{HASIL DAN PEMBAHASAN}

\section{HASIL}

Hasil kuisioner mengenai aspek minat belajar peserta didik pada pembelajaran STEM Robotik dianalisis dan dikonversi dalam bentuk persentase. Hasil pengolahan untuk setiap aspek tersebut menunjukkan gambaran minat belajar peserta didik terhadap pembelajaran STEM Robotik. Adapun hasil analisis tiga aspek minat belajar peserta didik sebagai berikut:

\section{Aspek Perhatian Peserta Didik Selama Pembelajaran STEM Robotik}

Perhatian peserta didik selama pembelajaran menjadi salah satu aspek minat belajar peserta didik ketika pembelajaran STEM Robotik berlangsung. Aspek perhatian peserta didik ini terdiri dari beberapa indikator, yaitu 1) menunjukan rasa ingin tahu, 2) menunjukkan antusiasme dalam pembelajaran, 3) mengikuti arahan selama pembelajaran, 4) aktif bertanya dalam pembelajaran, 5) mengikuti pembelajaran dengan sungguh-sungguh, dan 6) mempersiapkan pembelajaran dengan baik.

Hasil analisis dari kuisioner mengenai 6 indikator dalam aspek perhatian peserta didik dalam pembelajaran dapat dilihat pada gambar berikut ini:

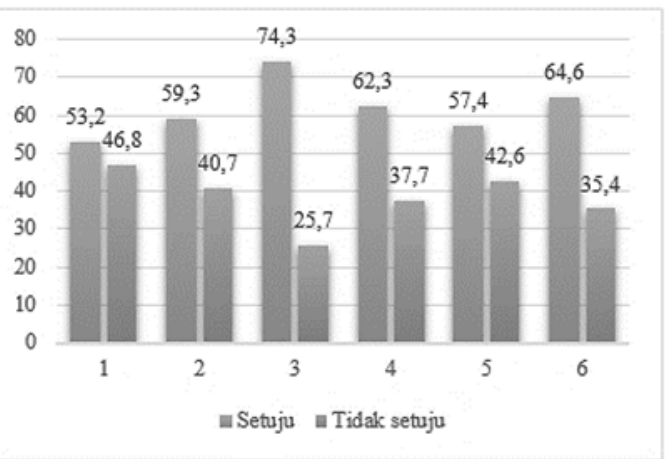

Gambar 1. Persentase Minat Belajar Peserta Didik Pada Aspek Perhatian Selama Pembelajaran STEM Robotik

Berdasarkan gambar 1 terlihat bahwa secara umum peserta didik memberikan respon positif untuk semua pernyataan aspek perhatian dalam pembelajaran STEM Robotik. Para peserta didik memberikan tanggapan bahwa pembelajaran STEM Robotik menjadikan rasa ingin tahu yang lebih selama pembelajaran, menjadikan peserta didik lebih antusias pada saat pembelajaran, membuat peserta didik mengikuti arahan guru selama pembelajaran. menjadikan peserta didik menjadi lebih aktif bertanya dalam proses pembelajaran dan menjadikan peserta didik lebih mempersiapkan diri dengan baik ketika akan menghadapi pembelajaran. Berdasarkan data persentase untuk setiap indikator tersebut diperoleh rata-rata persentase untuk aspek perhatian peserta didik dalam pembelajaran sebesar $61,8 \%$.

\section{Aspek Keterlibatan Peserta Didik Selama Pembelajaran STEM Robotik}

Keterlibatan peserta didik selama pembelajaran menjadi salah satu aspek minat belajar peserta didik dalam pembelajaran. Aspek keterlibatan peserta didik selama pembelajaran yang diukur dalam penelitian ini terdiri dari dua indikator, yaitu mengerjakan dan mengumpulkan tugas mandiri dan terlibat aktif dalam pengerjaan projek kelompok.

Adapun hasil analisis terhadap kuisioner mengenai indikator aspek keterlibatan peserta didik dalam pembelajaran STEM Robotik dapat dilihat pada gambar 2 berikut: 
Minat Belajar Peserta....

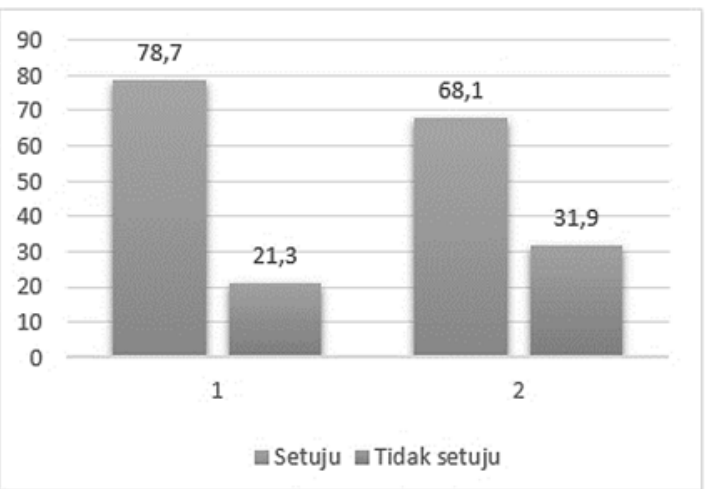

Gambar 2. Persentase Minat Belajar Peserta Didik Pada Aspek Keterlibatan Selama Pembelajaran STEM Robotik

Berdasarkan gambar 2 terlihat bahwa secara umum peserta didik memberikan respon setuju berkaitan aspek keterlibatan dalam pembelajaran STEM Robotik. Peserta didik menyatakan bahwa pembelajaran STEM Robotik menjadikan peserta didik menjadi memiliki inisiatif dalam mengerjakan dan mengumpulkan tugas. Pada pernyataan lain, peserta didik menyatakan bahwa pembelajaran STEM Robotik memberikan kesempatan untuk terlibat aktif dalam penyelesaian projek kelompok. Rata-rata persentase untuk indikator pada aspek keterlibatan peserta didik ini sebesar $73,4 \%$.

\section{Aspek Kebermanfaatan dalam Pembelajaran STEM Robotik}

Aspek lain dalam minat belajar peserta didik dalam pembelajaran STEM Robotik berkaitan dengan manfaat yang diperoleh peserta didik dari pembelajaran STEM Robotik. Untuk aspek ini terdiri dari 5 indikator yang diukur, yaitu respon peserta didik dalam: 1) manfaat yang diperoleh dalam meningkatkan kolaborasi, 2) manfaat yang diperoleh dalam meningkatkan literasi teknologi, 3) manfaat yang diperoleh dalam meningkatkan keterampilan merekayasa, 4) manfaat yang diperoleh dalam meningkatkan keterampilan berpikir, dan 5) manfaat yang diperoleh dalam meningkatkan aktvitas hands on dan minds on.

Adapun hasil analisis terhadap kuisioner pada aspek kebermanfaatan ini sebagai berikut:

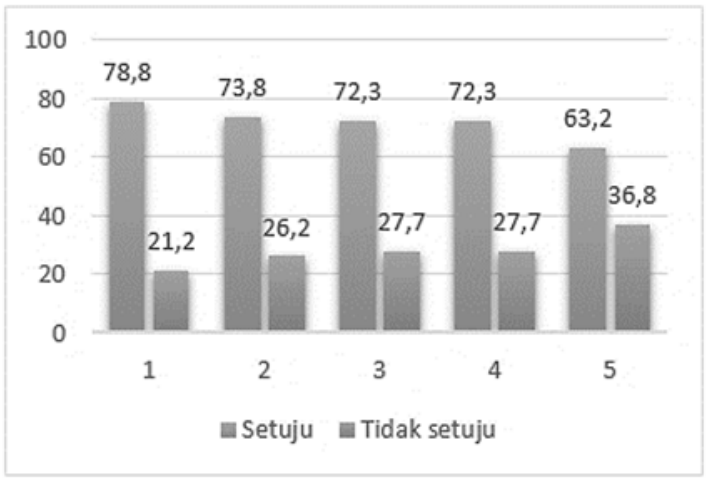

Gambar 3. Persentase Minat Belajar Peserta Didik Pada Aspek Kebermanfaatan Selama Pembelajaran STEM Robotik

Pada gambar 3 terlihat bahwa secara umum minat belajar peserta didik untuk aspek kebermanfaatan mendapatkan respok yang positif. Peserta didik menyatakan setuju bahwa pembelajaran STEM Robotik memberi manfaat dalam meningkatkan keterampilan kolaboratif meningkatkan literasi teknologi, meningkatkan keterampilan rekaya, meningkatkan keterampilan berpikir, dan meningkatkan aktivitas hands on dan minds on peserta didik selama proses pembelajaran berlangsung. Berdasarkan persentase setiap indikator pada aspek manfaat pembelajaran yang diperoleh peserta didik didapatkan rata-rata persentase sebesar $71,6 \%$.

\section{PEMBAHASAN}

Data kuisioner untuk setiap aspek minat belajar peserta didik yang sudah dianalisis dan dikonversi dalam bentuk persentase dibahas secara deskriptif sehingga memperoleh kesimpulan mengenai gambaran minat belajar peserta didik dalam pembelajaran STEM dengan media robot edukasi (STEM Robotik). Pembahasan disajikan untuk setiap aspek minat belajar peserta didik dengan memperhatikan indikator pada setiap aspeknya.

\section{Aspek Perhatian Peserta Didik Selama Pembelajaran STEM Robotik}

Pada aspek perhatian peserta didik selama pembelajaran STEM Robotik, secara umum peserta didik menunjukkan minat belajar yang baik untuk semua indikator aspek tersebut. Pembelajaran STEM Robotik menggunakan 
Minat Belajar Peserta....

media robot edukasi yang masih jarang digunakan oleh para peserta didik, dengan demikian sebagian besar dari peserta didik mendapatkan sesuatu yang baru dalam pembelajaran STEM Robotik ini. Kondisi ini menjadikan sebagian besar peserta didik menunjukkan rasa ingin tahu yang tinggi dan antusiasme yang tinggi ketika pembelajaran berlangsung.

Selain indikator rasa ingin tahu dan antusias, adanya integrasi robot edukasi dalam pembelajaran STEM pun menjadikan peserta didik secara aktif bertanya kepada guru mengenai projek STEM yang menggunakan robot edukasi serta mengikuti dengan baik setiap arahan yang disampaikan guru. Hasil ini sejalan dengan hasil penelitian Mosley, P., Ardito, G., dan Scollins, L. (2016) yang menyatakan bahwa lingkungan pembelajaran yang diciptakan dalam kolaborasi robotik dan STEM dapat meningkatkan keaktifan peserta didik dalam bertanya mengenai eksperimen yang akan dilaksanakan. Bahkan lebih dari itu, hasil kuisioner menunjukkan bahwa peserta didik mempersiapkan pembelajaran STEM Robotik ini dengan sungguh-sungguh sehingga diharapkan mampu menyelesaikan setiap projek STEM Robotik dengan baik.

Hasil penelitian tersebut menunjukkan bahwa pembelajaran STEM Robotik mendapatkan respon yang baik dari para peserta didik, khususnya dalam minat belajar melalui pemberian perhatian selama proses pembelajaran berlangsung. Hasil penelitian ini sejalan dengan penelitian Anwar, et al (2019) yang menyatakan bahwa integrasi robot edukasi dalam pembelajaran STEM dapat meningkatkan minat belajar peserta didik ketika mempelajari konsep yang berhubungan dengan STEM.

\section{Aspek Keterlibatan Peserta Didik Selama Pembelajaran STEM Robotik}

Keterlibatan secara aktif dalam pembelajaran menjadi salah satu aspek yang menunjukkan minat belajar. Pada penelitian ini terdapat dua indikator yang diukur pada aspek keterlibatan, yaitu inisiatif dalam penyelesaian tugas atau projek dan aktif berkontribusi dalam penyelesaian projek kelompok. Secara umum untuk kedua indikator aspek tersebut, peserta didik menunjukkan minat belajar yang baik ketika pembelajaran STEM Robotik berlangsung. Peserta didik menyatakan pembelajaran STEM Robotik menjadikan mereka lebih inisiatif dalam menyelesaikan tugas atau projeknya.

Selain inisiatif dengan tugas atau projeknya, peserta didik pun menyatakan bahwa pembelajaran STEM Robotik menjadikan peserta didik aktif dalam kontribusi penyelesaian projek STEM Robotik dalam kelompok. Hasil ini sejalan dengan penelitian sebelumnya Latip, A., et al (2020) yang menemukan bahwa peserta didik yang mempelajari STEM dengan bantuan robot edukasi memiliki peningkatan keterampilan kolaborasi pada aspek paritispasi aktif dalam menyelesaikan projek individu dan kelompok dengan kategori peningkatan medium ( $\mathrm{N}$-gain= $0,56)$. Hasil ini sejalan juga dengan hasil kajian Anwar, S (2019) yang menyatakan bahwa STEM dengan robot edukasi dapat menciptakan pembelajaran yang aktif dan melibatkan peserta didik.

\section{Aspek Manfaat yang diperoleh dalam Pembelajaran STEM Robotik}

Minat belajar peserta didik terhadap pembelajaran dapat dilihat juga dari aspek manfaat yang diperoleh peserta didik saat dan setelah mempelajari mata pelajaran tersebut. Pada pembelajaran STEM Robotik, minat belajar aspek manfaat ditinjau dari 5 indikator yang menggambarkan manfaat yang diperoleh peserta didik setalah melakukan pembelajaran STEM dengan media robot edukasi. Secara umum, peserta didik menyatakan mendapatkan manfaat setelah mengikuti pembelajaran STEM Robotik, manfaat yang diperoleh berkaitan dengan peningkatan berbagai keterampilan.

Peningkatan berbagai keterampilan yang dirasakan dan diperoleh peserta didik dari pembelajaran STEM Robotik pada lima indikator aspek manfaat ini sejalan dengan beberapa penelitian yang menunjukkan bahwa pembelajaran STEM Robotik meningkatkan aktivitas hands on dan minds on (Jiea, et al, 2018; William, et al, 2012), meningkatkan keterampilan berkolaborasi peserta didik (Latip, A., et al., 2020; Sahin, A., Ayar, M. C., \& Adiguzel, T, 2014), meningkatkan keterampilan rekayasa (Eghuci, 2013), meningkatkan 
keterampilan teknologi (Carik dan Guven, 2019), dan meningkatkan keterampilan berpikir (Karaahmetoglu dan Korkmaz, 2019).

Hasil kuisioner peserta didik pada indikatorindikator dari aspek manfaat yang sejalan dengan beberapa penelitian tersebut menunjukkan bahwa STEM Robotik memberikan dampak positif untuk peserta didik pada peningkatan berbagai keterampilan. Jika peserta didik sudah merasakan manfaat dari STEM Robotik untuk peningkatan keterampilan, maka minat belajar peserta didik pada STEM Robotik pun diharapkan akan semakin meningkat.

\section{PENUTUP}

STEM dengan media robot edukasi merupakan salah satu inovasi dalam pembelajaran STEM. Implementasi STEM Robotik dalam kurikulum reguler diharapkan meningkatkan berbagai keterampilan dan minat belajar peserta didik. Hasil penelitian menunjukkan bahwa peserta didik memiliki minat belajar yang baik dalam pembelajaran STEM Robotik. Minat belajar tersebut terlihat dari tiga aspek yang diukur, yaitu perhatian peserta didik, keterlibatan peserta didik, dan manfaat yang diperoleh peserta didik. Ketiga aspek tersebut mendapatkan repson baik dan positif dari peserta didik yang memberikan gambaran mengenai minat belajar peserta didik pada pembelajaran STEM Robotik.

\section{DAFTAR PUSTAKA}

Anwar, S., Bascou, N. A., Menekse, M., \& Kardgar, A. (2019). A Systematic Review of Studies on Educational Robotics. Journal of Pre-College Engineering Education Research. 9 (2). 19-42.

Blackley dan Howell. (2019). The Next Chapter in the STEM Education Narrative: Using Robotics to Support Programming and Coding. Australian Journal of Teacher Education. 44(4), 51-64.

Cakir, NK., dan Guven, G. (2019). ArduinoAssisted robotic and coding applications in science teaching: Pulsimeter activity in compliance with the $5 \mathrm{E}$ learning model. Journal Science Activities. 56(2). 42-51..
Chen dan Chang. (2018). The Impact of an Integrated Robotics STEM Course with a Sailboat Topic on High School Students' Perceptions of Integrative STEM, Interest, and Career Orientation. EURASIA Journal of Mathematics, Science and Technology Education. 14(12), 1-19.

Ebelit, R. (2012). The Effects of a Robotics Program on Students Skills in STEM, Problem Solving and Teamwork. Tesis. Science Education. Montana State University. Bozeman, Montana.

Eguchi. A. (2013). Educational Robotics for Promoting 21st Century Skills. Journal of Automation, Mobile Robotics \& Intelligent Systems. 8(1), 5-11.

Gura, M. (2011). Getting Started with LEGO Robotics: A Guide for K-12 Educators. Retrieved 22 Dec. 2019, from http://www.iste.org/images/excerpts/ROB OTS-excerpt.pdf.

Jiea P. Y., Hanipah H., dan Sharifah S.S.A. (2018). Integrated Robotics STEM Curriculum Towards Industry 4.0. International Journal of Human and Technology Interaction. 2(2), 17-23.

Karaahmetoglu dan Korkmaz. (2019). The effect of project-based arduino educational robot applications on students' computational thinking skills and their perception of Basic STEM skill levels. Participatory Educational Research (PER). 6(2). 1-14.

Khanlari. (2013). Effects of Educational Robots on Learning STEM and on Students' Attitude Toward STEM. 2013 IEEE 5th Conference on Engineering Education (ICEED). 62-66.

Lantz Jr., H.B. (2009). Science, Technology, Engineering, and Mathematics (STEM) Education What Form? What Function? Retrieved 20 December 2019, from http://www.currtechintegrations.com/pdf/S TEMEducationArticle.pdf.

Latip, A., dan Hardinata, A. (2020). Implementation of STEM-Robotics as High School Intracurricular. Thabiea: Journal of Natural Science Teaching, 3(1), 11-19.

Latip, A., Andirani, Y. Purnamasari, S. dan Abdurrahman, D. (2020). Integration of 
educational robotic in STEM learning to promote students' collaborative skill. J. Phys.: Conf. Ser. 1663. 012052.

Mosley, P., Ardito, G.; dan Scollins, L. (2016). Robotic Cooperative Learning Promotes Student STEM Interest. American Journal of Engineering Education. 7 (2), 117-128.

Sahin, A., Ayar, M. C., \& Adiguzel, T. (2014). STEM-related after-school program activities and associated outcomes on student learning. Educational Sciences: Theory and Practice, 14(1), 309-322.

Permanasari, A. (2016). STEM Education: Inovasi dalam Pembelajaran Sains. Prosiding Seminar Nasional Pendidikan Sains (SNPS). 23-34.

Whitehead, S.H., (2010). Relationship of Robotic Implementation on Changes in Middle School Students' Beliefs and Interest Toward Science, Technology, Engineering and Mathematics. Doctor of Education Dissertation. Indiana University of Pennsylvania.

Williams, K., Igel, I., Poveda, R., Kapila, V., \& Iskander, M. (2012). Enriching K-12 science and mathematics education using LEGOs. Advances in Engineering Education, 3(2). 1-27. 